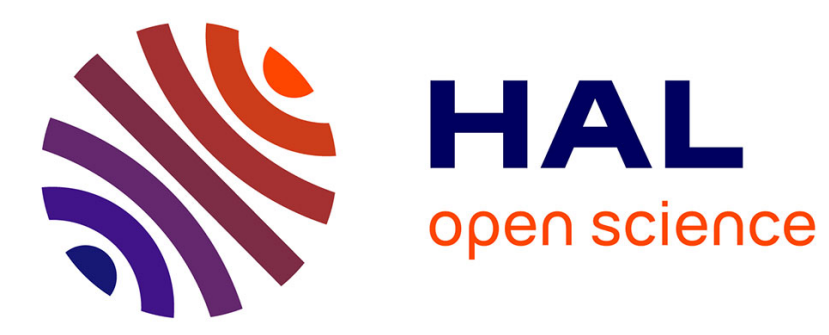

\title{
Intimations of Mortality: Death's Shadow in Updike's Oeuvre
}

\author{
Sylvie Mathé
}

\section{To cite this version:}

Sylvie Mathé. Intimations of Mortality: Death's Shadow in Updike's Oeuvre. European Perspectives on John Updike, 2018. hal-01911891

\section{HAL Id: hal-01911891 \\ https://hal.science/hal-01911891}

Submitted on 4 Nov 2018

HAL is a multi-disciplinary open access archive for the deposit and dissemination of scientific research documents, whether they are published or not. The documents may come from teaching and research institutions in France or abroad, or from public or private research centers.
L'archive ouverte pluridisciplinaire HAL, est destinée au dépôt et à la diffusion de documents scientifiques de niveau recherche, publiés ou non, émanant des établissements d'enseignement et de recherche français ou étrangers, des laboratoires publics ou privés. 


\title{
3: Intimations of Mortality: Death's Shadow in Updike's Oeuvre
}

\author{
Sylvie Mathé
}

Life is a shabby subterfuge while death is real, and dark, and huge.

-John Updike, "Requiem"

N HIS MOVING TRIBUTE to Updike, $U$ and $I$, a strange metacritical, ante-
mortem eulogy prompted by the death of a fellow writer, Donald
Barthelme, Nicholson Baker (1991) writes:

All I wanted, all I counted on, was Updike's immortality, his openended stream of books, reviews, even poems. . . . He was, I felt, the model of the twentieth-century American man of letters: for him to die would be my generation's personal connection with literature to die. ... "I should," I typed that morning, "write some appreciation" of Updike. And "it has to be done while he is alive." (13)

Later in the book, Baker gets to the gist of what he is undertaking: "Memory criticism, understood as a form of commentary that relies entirely on what has survived in a reader's mind . . is possibly a new and useful way of discussing literature" (88).

The notion of "memory criticism" may sound heretical or at least unorthodox in academia, but Baker here touches on a profound truth that has to do with the perennity of the writer-his "ticket to immortality" (Baker, 143), as Updike himself puts it. Though Baker had the foresight to write his tribute some eighteen years before Updike's death, our own lament as readers may best be given voice by Martin Amis's (2009) response in the Guardian to the news of Updike's death in 2009: "Several times a day you turn to him, as you will now to his ghost, and say to yourself, 'How would Updike have done it?' This is a very cold day for literature."

As the first decade of our orphanage as readers and, perhaps, as writers is coming to a close, homage to Updike can perhaps find its natural locus in the more haunting images in his work, in particular those images that reveal a pentimento of death, despite his celebrated "yea-saying."

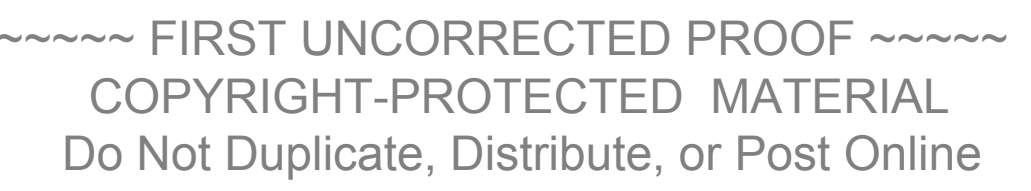



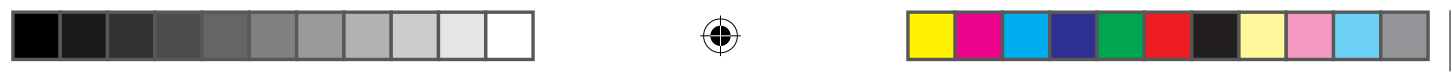

Diverging from the familiar readings in Updike critical studies that have tended to foreground the life-affirming, salvation-oriented aspects of his work (for example, Burchard 1971), this essay seeks to map Updike's journey into night and to sound the grief that, like a basso continuo, accompanies author and readers alike up to, in Henry James's (1909) phrase, "the point where the death comes in" (317).

Indeed, from his earliest short stories to his last collection of poems, Endpoint, death's shadow hovers over and runs through Updike's work, alternately buried and subterranean or surfacing in epiphanies of immortality or visitations of mortality. Of course, "Pigeon Feathers" constitutes Updike's signature narrative of the waiving of the fear and horror of death in an irresistible intimation of immortality. David Kern's "exact vision of death"- "He was alone. In that deep hole" (ES, 17, 27)-gives way to the certainty not only of God's existence but of his own immortality. In the celebrated climax of this short story, "he was robed in this certainty: that the God who had lavished such craft upon these worthless birds would not destroy His whole Creation by refusing to let David live forever" $(E S, 33)$. This paradoxical a contrario proof-a variation of apophatic theology - lifts the adolescent David out of the "ocean of horror" $(E S, 26)$ that had threatened to engulf him in nothingness. Yet set back in its context, this intimation of immortality resonates against a series of "small deaths" that Updike chronicles in these Olinger stories: "Flight," for instance, or "The Happiest I've Been" retrace epiphanies that were lived in the moment as flights of liberation coinciding with the breaking free of adolescence into adulthood, the going through into manhood, but that retrospectively become "small deaths." Updike's late Pennsylvania story, "My Father's Tears," will thus render in its full pathos what the author memorably describes in his conversation with Charles T. Samuels (1994) as "the irremediable grief in just living, in just going on" (28): "But my father did foresee, the glitter in his eyes told me, that time consumes us-that the boy I had been was dying if not already dead, and we would have less and less to do with each other" (MFT, 195). Imbued with a retrospective sense of nostalgia, the Olinger stories at once irradiate a kind of eternal innocence while mourning what Wordsworth (1994) calls the "hour[s] of splendour in the grass" (590). The finale of the last Olinger story, the Proustian "In Football Season," resonating like a dirge, thus captures in all its poignancy the punctum of this Paradise Lost: "Girls walk by me carrying their invisible bouquets from fields still steeped in grace and I look up in the manner of one who follows with his eyes the passage of a hearse, and remembers what pierces him" (ES, 125). The notion of "small death," in George Bataille's memorably metaphoric phrase, to qualify the ecstasy of orgasm ("la petite mort"), of course reverberates throughout Updike's oeuvre, linked with the glory of sex, but inevitably shadowed by postcoital sadness. The motif of eros and thanatos

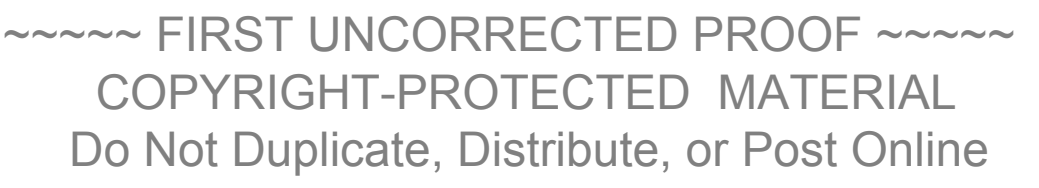


("Love and death, they can't be pried apart any more" [ $R A, 1234])$, one of the red threads that runs through most if not all of Updike's fiction, has given rise to an abundant body of critical work. It plays its most seminal role in the Rabbit tetralogy.

Rabbit, of course, is "Mr. Death," as his mistress Ruth aptly renames him in the last pages of Rabbit, Run, and the mysterious elusive "it" that governs his quest in this first installment turns out in the end to be nothing but death itself: "Whatever it is, it now has found him, and is working him over" $(R A, 1172)$. The "hardness of the heart" mentioned in Pascal's epigraph- "The motions of Grace, the hardness of the heart; external circumstances" $(R A, 4)$-will in fact literalize itself into the fatal plaque that hardens Rabbit's arteries and will cause his massive heart attack in Rabbit at Rest: in Updike's words, "the hardened heart becomes no longer a metaphor, but an actual physical thing" (quoted in Bragg 1994, 228). From 1959 to 1989, we thus follow thirty years on the path to death of a doppelgänger of sorts of the author, but above all also an Everyman. As Joyce Carol Oates (1990) writes in her review of Rabbit at Rest, "Updike's courageous theme [is] the blossoming fruition of the seed of death we all carry inside us." The Pennsylvania quartet reads like an anamorphosis of death, through a complex network of imagery linking the "radiance and darkness" of nature, to borrow a phrase from the early story "Packed Dirt, Churchgoing, A Dying Cat"- "Matter has its radiance and its darkness; it lifts and it buries" (ES, 106)-and weaving the cycles of life and death, the revolving of seasons and the passing of generations. ${ }^{l}$ From the first pages onward, it is the skull showing through the hair on Janice's head that initially haunts Rabbit and prompts his desperate quest for antidotes to this engulfing fear of death, only leading to further despair: "He feels the truth. . . . The fullness ends when we give Nature her ransom, when we make children for her. Then she is through with us, and we become, first inside, and then outside, junk. Flower stalks ..." (RA, 193-94). The irony is that sex, as "soul food" $(R A, 1229)$ and an antidote to the fear of death, should, like the pharmakos, turn into a further dose of poison, yet another plunge into nothingness: "Nature leads you up like a mother and as soon as she gets her little contribution leaves you with nothing" $(R A, 75)$. Similarly, Rabbit's walk with Ruth to the top of Mount Judge on a beautiful Sunday afternoon, which he undertakes in a spirit of elation, in a text fraught with references to a pilgrimage, opens for him a vista of desolation and triggers a vision of death: "Someone is dying. In this great stretch of brick someone is dying" ( $R A$, 98). The progressive form, as well as the repetition, emphasizes the very process of death at work in the here and now, as a kind of proleptic heralding of the baby's impending death.

Like movements in a sonata or a symphony, the next volumes of the tetralogy each proceed at a musical pace and with a textual flavor all their

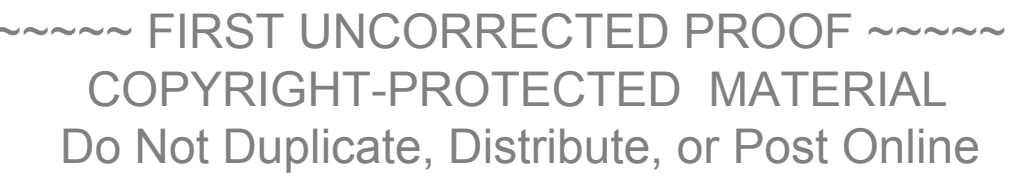



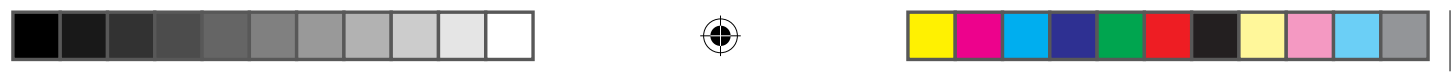

own, while embroidering the same basic motifs. Rabbit Redux, the most apocalyptic of the series, is a borderline experience-cacophonic and catatonic at once-an experience with chaos and nothingness that turns lethal in many ways and ends in devastation, while the allegro spirit of Rabbit Is Rich lifts the saga into the golden haven of wealth, "safe at last in the middle years" (the title of Margaret Gullette's [1988] study), even if Rabbit is more akin to the "Rabbit as King of the Ghosts" of Wallace Stevens's epigraph than to his fatuous ancestor Babbitt. The sense of mortality increases as the years go by and as the shadows lengthen on Rabbit's fur: Harry, who "for the first time since childhood . . . is happy, simply, to be alive" $(R A, 629)$, takes up running again, as a hobby, this time, and a healthy habit, and the ghosts of the dead accompany him on his jogs as brotherly souls, like Whitman's leaves of grass under his foot soles:

Like these swallows Rabbit, the blue and gold of his new shoes flickering, skims, above the earth, above the dead. The dead stare upwards. ... He is treading on them all, they are resilient, they are cheering him on, his lungs are burning, his heart hurts, he is a membrane removed from the hosts below, their filaments caress his ankles, he loves the earth, he will never make their mistake and die. $(R A, 748)$

While he rejoices that "the great thing about the dead [is that] they make space" $(R A, 1002)$, and while he basks in the glory of living and experiences anew the sense of immortality that he felt in his youth as a high-school sports hero, he also senses the dead calling and beckoning to him: "The dead, Jesus. They were multiplying, and they look up begging you to join them, promising it is all right, it is very soft down here. Pop, Mom, old man Springer, Jill, the baby called Becky for her little time, Tothero. Even John Wayne, the other day" $(R A, 629)$. Strangely at peace with himself and the world, no longer prey to fear and trembling, Rabbit in Rabbit Is Rich is indeed "King of the ghosts," "radiant and sad" (RA, 1002). This happy break, however, is but a parenthesis in the deceptive process of descent into nothingness. The insulation provided by riches, associated through the metaphorical network of the novel to feces, connects wealth and death. The anality of hoarding gold and silver leads in the end to the black casket of nothingness that Harry sexually experiences with Thelma during his revelation of sodomy, "a void, a pure black box, a casket of perfect nothingness" ( $R A, 1000)$.

The next and final installment, Rabbit at Rest, has been described by the author as "a depressed book about a depressed man, written by a depressed man" (Updike 1990, 25). Updike, who was only 58 at the time, was bidding his farewells - to his mother, who died while he was just finishing the first draft, to his beloved character Harry Angstrom, and to Pennsylvania:

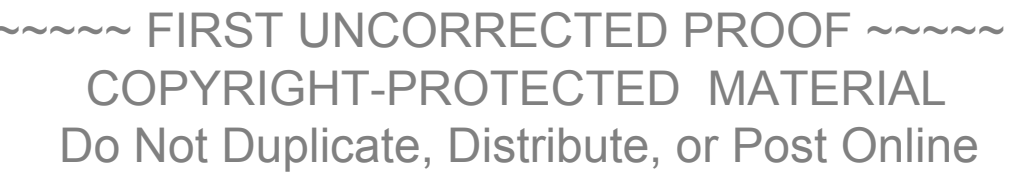



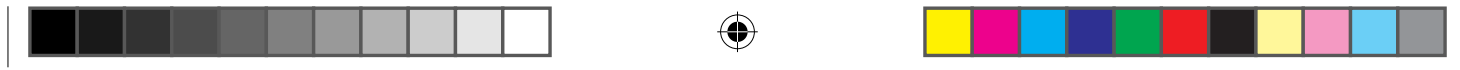

INTIMATIONS OF MORTALITY

Deciding to wind up the series was a kind of death for me. Even though I left Pennsylvania in the early 50's, as long as my parents were alive I had a living link with the state. My father died in 1972 but my mother lived on, and so I had continuing reasons to visit Rabbit's territory, to refresh my sense of it and check up on changes. But as she became older I saw that my link would end someday, and end with it my grip on Rabbit's world. My mother died in October, 10 days after I finished the first draft; her dying became interwoven with my own sense of aging and my hero's even more severe sense of aging. (Updike 1990, 25)

But then again, as James Schiff (1998) writes, "the accomplishment of this elegiac novel was that Updike was able to make a depressing work vibrant, an age-old subject fresh, a predictable ending poignant" (57).

Rabbit's death, on September 22, 1989, preceded the fall of the Berlin Wall by a few weeks. Nearly thirty years have now passed, and his world is dead, but we cannot help asking such questions as, What would Rabbit have made of $9 / 11$ or of the war on terror, or the election of Donald Trump? The strange denouement of the bombing of Pan Am Flight 103 over Lockerbie-the release by the Scottish government in 2009 of the main perpetrator to his home country, Libya, where he was acclaimed as a hero before Libya itself collapsed into chaos in one of the twists of the Arab spring - rings further echoes. Harry, at the beginning of the last volume, "has a funny feeling that what he has come to meet ... is not [his family] but something more ominous and intimately his: his own death, shaped vaguely like an airplane." He pictures in his mind "those bodies tumbling down like wet melon seeds" and cannot help feeling that "he too is falling, helplessly falling, toward death" $(R A, 1057$, 1209). The heartbreaking, elegiac ring of this last volume comes from the ever-pressing intimations of death, of the passage unto death, that keep assailing the central character, Updike's alter ego of sorts. Sometimes these intimations come like a flash of pure grace, as when, in the opening pages of part 2 (entitled "PA"), following his angioplasty, Rabbit drives through a white tunnel of Bradford pear trees in full bloom on a Brewer street and feels as though he has blundered into a piece of Paradise. As he later tells his daughter, Annabelle, "'Tell your mother we'll meet some other time,' thinking 'Under the pear trees, in paradise'" $(R A, 1316)$. When he evokes this heavenly vision with Janice, her indifferent answer nevertheless points to the deep truth that, having been so close to death on the hospital table, he now sees differently: "You've seen, it's just you see differently now" $(R A, 1220)$. Like his own shadow, the list of the dead is further lengthening, and his mind is continually haunted by those who have recently died, fictional as well as real: Jimmie the Mouseketeer, Peggy Fosnacht, Thelma Harrison, or Bart Giamatti, the late professor of

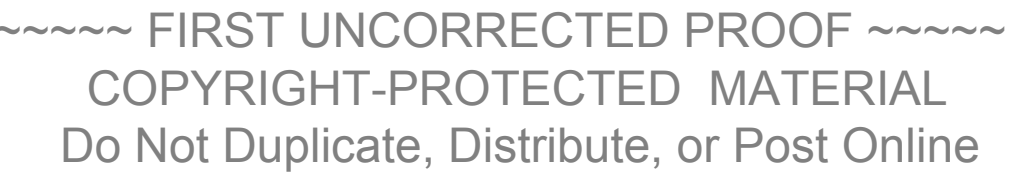



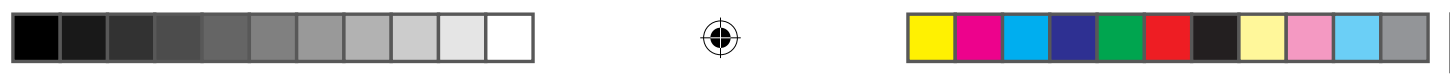

English Renaissance literature, former Yale president, and seventh commissioner of Major League Baseball, whose name recurs like a funeral dirge through the last pages of the volume- "Only fifty-one ... Just think, he lay down for lunch and that was it" $(R A, 1456,1458)$.

Rabbit is haunted as well by "something tragic in matter itself, the way it keeps watch no matter how great our misery" $(R A, 1351)$. This echo of Updike's autobiographical piece "The Dogwood Tree: A Boyhood," in which he exalts the "quiet but tireless goodness that things at rest, like a brick wall or a small stone, seem to affirm" $(A P, 83)$, is perhaps an index of the writer's evolution over this thirty-year period. The sense of reassurance has become a tragic sense. Moreover, Rabbit is obsessed by the conviction that "We're all trash, really. Without God to lift us up and make us angels we're all trash" $(R A, 1362)$. The narrative's steady descent toward death foregrounds the physical and social entropy of America at the same time as it reflects the slow transformation of the character into "garbage," "junk," as witnessed by his pitiful performance as Uncle Sam for the Fourth of July parade in his native town. Rabbit's helpless absorption of junk food is yet another literal rendering of the entropic process that will transform his body into a walking piece of junk, bloated and corroded.

His last flight takes him to the "mass-produced paradise" of Florida, "death's favorite state" $(R A, 1196)$, whose "mortuary calm" $(R A, 1077)$ feels more necrotic than erotic, where he will meet his end. The name of his Florida condominium, Valhalla Village, recalls the Norse warriors slain in battle, a fitting locale indeed for our Swedish basketball hero, soon to be slain in his last battle on the court. Neither maudlin nor clichéd, the deathbed scene is Rabbit's attempt at reconciliation with all around him and concludes on his last words to his son Nelson. These are words of appeasement and almost relief, words that reflect the "higher and more remote vision" that René Girard (1976), in Deceit, Desire and the Novel, pinpoints as the hallmark of renouncement in death: "all I can tell you is, it isn't so bad." The final word, "Enough," repeated twice but modulated by the tentative "Maybe" $(R A, 1516)$, reads like a surrender-the finally achieved rest of the warrior.

Yet in the final installment of the saga, "Rabbit Remembered" (originally titled "Nelson and Annabelle" in the New Yorker), Rabbit will rise like the phoenix, and Nelson and Annabelle will turn out to be Rabbit's unlikely promising legacy. The shadow that hovers over this final Rabbit novella seems in the end a benevolent one, contrary to some of the more hostile figures of the dead that appear in the later short stories, such as "A Sandstone Farmhouse," with its evocation of "the peace of the dead, their final and, as it were, hostile withdrawal" (After, 132), or even more tellingly, "The Journey to the Dead," with its mythological references and its snippets of ancient texts: "There beset me ten thousand seely ghosts,

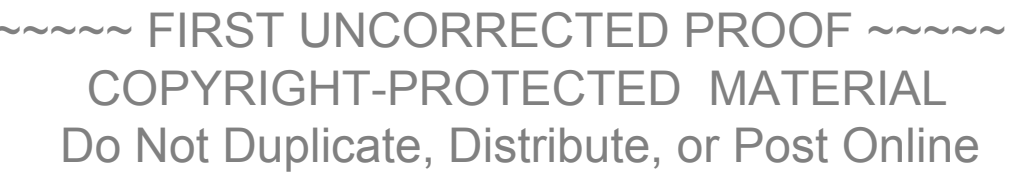



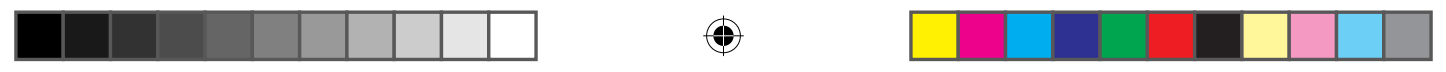

crying inhumanly" (After, 71). Focusing more than any other story on the last stages of life, the process of dying and the dying themselves, as well as on the forbidding and forbidden approach of the dead, "The Journey to the Dead" resonates as a masterful metaphoric construct that exploits two of the mythic schemes of death: the descent to the underworld and the evocation of the dead. ${ }^{2}$ As William Pritchard (2000) fittingly writes, "I don't know of any single story in Updike's work, or another writer's, that more unflinchingly, and with something like human dignity, confronts us with our lot. It may be thought of as a sad postscript to the boy's final conviction when he buries the pigeons in 'Pigeon Feathers"' (325-26).

The late stories, gathered in My Father's Tears, thus appear increasingly concerned with the dying and the dead, at the same time as they close the loop on the earlier Pennsylvania stories. Featuring recurring personae and familiar settings that the numerous decades between have defamiliarized and rendered alien, these stories ponder the mystery of lost time. The high-school reunion settings that figure prominently in "The Road Home" or "The Walk with Elizanne" provide the suitable framework for a bemused Proustian look over the abyss of time: "Elizanne, he wanted to ask her, what does it mean, this enormity of our having been children and now being old, living next door to death?" (MFT, 52).

In one of his last essays, on the subject of "Late Works," Updike probes the enigma of death from still another angle: "Yet, at least for this aging reader, works written late in a writer's life retain a fascination. They exist, as do last words, where life edges into death, and perhaps have something uncanny to tell us" ( $D C, 50)$. His own last words are of course those of the Endpoint sequence of poems that appeared posthumously in the New Yorker, triggering the same shock of recognition that Rabbit's resurrection, under the features of his daughter, produced for the bemused Nelson on the threshold of his house. No longer standing at "midpoint" on the path of life as in Dante's opening line- "Nel mezzo del cammin di nostra vita" 3 - the writer was approaching death as he wrote them. Their retrospective vistas and diary-like notations open onto a kind of testamental intimacy, as in the poem "Hospital $11 / 23-27 / 08$," written at Massachusetts General in Boston. In the most moving of these poems, "Peggy Lutz, Fred Muth 12/13/08," Updike salutes two of his former classmates, and this final tribute to these ghosts of the past stands out in its radiant simplicity as a form of oblation:

They've been in my fiction; both now dead,

Dear friends of childhood, classmates, thank you,

The "glory of the passing days" that the poem conjures upthe "heaven" that we meet in childhood-is Updike's version of Wordsworth's "hour of splendour in the grass" (Wordsworth 1994,

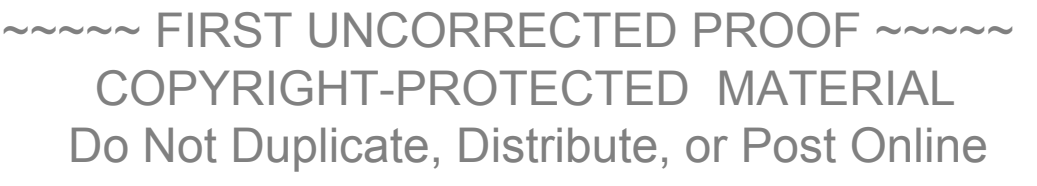



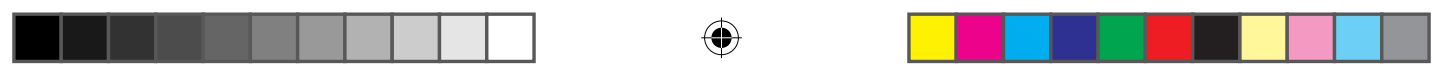

590). Yet the ending of the poem, with its soft anticlimax, sadly points to the complementary, rather than oxymoronic, link between life and death-"how drear and deadly life can be" (Endpoint, 27)—namely, the deadliness inherent in life itself.

This universal human deadliness could in some ways be said to have been Updike's raison d'etre as a writer. His career-long, lifelong preoccupation with mortality, which wormed its way into his writing from his earliest publications until his last, appeared to unite him with humanity in ways he found sustaining. Or as he writes in "Getting the Words Out," in ways that enabled him to express his "defective imperilled self" (Self, 100). His experience of illness, in particular the skin disorder psoriasis and the breathing disorder asthma, produced in him "some vacuum" (Self, 108), he writes, that made him yearn for "the papery self-magnification and immortality of printed reproduction" (Self, 108): "to be in print was to be saved" (Self, 108). By ventilating through publication his own anxieties about death, he perhaps achieved a kind of emotional communion with others, a communion less available to those in the world who do not offer permanent records of their own creativity.

In the last of his deathbed poems, "Fine Point," dated December 22, 2008, a mere five weeks before his death, Updike quotes from the beginning of Psalm 23:6: "Surely goodness and mercy shall follow me all the days of my life," echoing the kernel of his novel The Centaur- "Only goodness lives-but it does live" (Centaur, 267). But what the ending of the poem echoes is his autobiographical essay "On Being a Self Forever" in which he quotes Miguel de Unamuno- "I do not want to die-no; I neither want to die nor do I want to want to die; I want to live forever and ever and ever. I want this 'I' to live- this poor ' $I$ ' that I am and I feel myself to be here and now" (Self, 229). With the last two words, his parting words-"my life, forever" (Endpoint, 29)—Updike puts the final point, a farewell to his life and to his readers and a testament to our shared mortality.

\section{Notes}

${ }^{1}$ Having returned to the Rabbit novels following Updike's death, Julian Barnes writes: "Whereas [in] my first reading I was overwhelmed by Updike's joy of description, in my second I was increasingly aware of this underlying sense of things being already over, of the tug of dying and death" (quoted in Mazzeno $2013,187)$.

2 Cf. Mathé 1999 and Duffy 2012.

3 Cf. Updike 1969; Dante 1950. The opening line of Dante's Divine Comedy ("Nel mezzo del cammin di nostra vita") has been variously translated, but its meaning is generally understood as "At the midpoint of this, our mortal life." The allusions and structural parallels to Dante in the first canto of Updike's Midpoint are unmistakable.

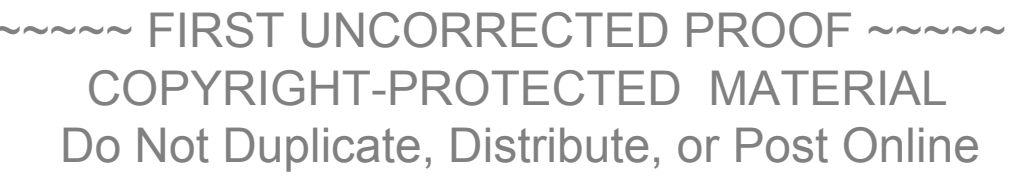



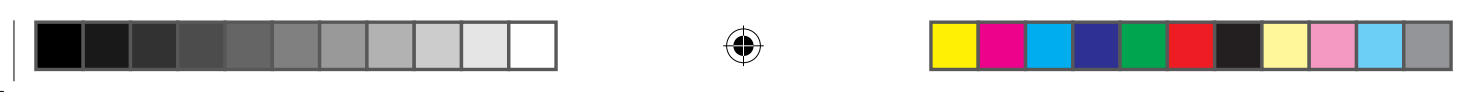

INTIMATIONS OF MORTALITY

\section{Works Cited}

Amis, Martin. 2009. "He Took the Novel onto Another Plane of Intimacy." Guardian, January 28. https://www.theguardian.com/books/2009/ jan/28/johnupdike-usa.

Baker, Nicholson. 1991. U and I. New York: Vintage Books.

Bragg, Melvyn. (1990) 1994. "Forty Years of Middle America with John Updike, 1990.” In Plath 1994, 221-28.

Burchard, Rachel. 1971. John Updike: Yea-Sayings. Carbondale: Southern Illinois University Press.

Dante (Alighieri). 1950. Divine Comedy: Hell. Translated by Dorothy L. Sayers. Harmondsworth: Penguin.

Duffy, Brian. 2012. "Motifs of Loss in The Afterlife." John Updike Review 2, no. $1: 31-49$.

Girard, René. 1976. Deceit, Desire and the Novel: Self and Other in Literary Structure. Translated by Yvonne Freccero. Baltimore: Johns Hopkins University Press.

Gullette, Margaret Morganroth. 1988. Safe at Last in the Middle Years. Berkeley: University of California Press.

James, Henry. 1909. The Ambassadors. New York: Scribner's.

Mathé, Sylvie. 1999. "Voyage au pays des morts: l'irréversible et la nostalgie dans 'The Journey to the Dead' de John Updike." In Voyageurs et Voyages, edited by Gérard Hugues, 27-47. Aix-en-Provence: Publications de l'Université de Provence.

Mazzeno, Laurence W. 2013. Becoming John Updike: Critical Perspectives 1958-2010. Rochester, NY: Camden House.

Oates, Joyce Carol. 1990. "So Young!" New York Times, September 30. http://www.nytimes.com/1990/09/30/books/so-young.html.

Plath, James, ed. 1994. Conversations with John Updike. Jackson: University Press of Mississippi.

Pritchard, William. 2000. Updike: America's Man of Letters. South Royalton, MA: Steerforth Press.

Samuels, Charles T. (1968) 1994. "The Art of Fiction XLIII: John Updike, 1968." In Plath 1994, 22-45.

Schiff, James. 1998 John Updike Revisited. Boston: Twayne.

Updike, John. 1963. The Centaur. Harmondsworth: Penguin.

. 1965. Assorted Prose. Harmondsworth: Penguin Books.

1969. Midpoint and Other Poems. New York: Knopf.

1989. Self-Consciousness. New York: Knopf.

1990. "Why Rabbit Had to Go." New York Times Book Review, August 5, 1 .

1994. The Afterlife, and Other Stories. London: Penguin Books.

1995. Rabbit Angstrom-A Tetralogy. New York: Knopf.

2003. The Early Stories 1953-1975. New York: Knopf.

2007. Due Considerations. New York: Knopf.

2009a. Endpoint and Other Poems. New York: Knopf.

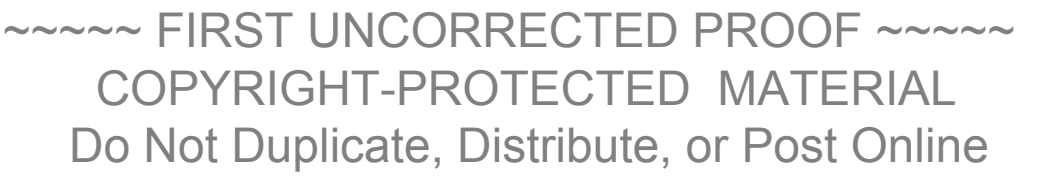



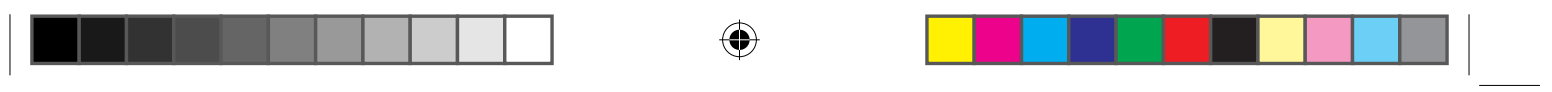

54 Sylvie Mathé

2009b. My Father's Tears. New York: Ballantine Books.

Wordsworth, William. 1994. The Collected Poetry of William Wordsworth.

Ware, Herts., UK: Wordsworth Editions Limited.

Do Not Duplicate, Distribute, or Post Online 